\title{
FACTORS AFFECTING STUDENT'S FINANCIAL LITERACY (A STUDY ON THE STUDENTS OF THE FACULTY OF ECONOMICS AND THE FACULTY OF SCIENCE AND TECHNOLOGY OF SANATA DHARMA UNIVERSITY YOGYAKARTA)
}

\author{
Erren Egesta \\ Department of Management, Faculty of Economics, Sanata Dharma University, Yogyakarta \\ Email:errenegesta21@gmail.com \\ Caecilia Wahyu Estining Rahayu \\ Department of Management, Faculty of Economics, Sanata Dharma University, Yogyakarta \\ Email: caecilia50@gmail.com
}

Christina Heti Tri Rahmawati*

Department of Management, Faculty of Economics, Sanata Dharma University, Yogyakarta Email: christinaheti.nugroho@yahoo.co.id

Received: July 2020; Accepted: December 2020; Available online: January 2021

\begin{abstract}
This study aims to determine 1) the factors that affect students' financial literacy. The factors include gender, Grade Point Average (GPA) and allowance; 2) the differences in financial literacy between students of the Faculty of Economics and students of the Faculty of Science and Technology. The population in this study were active students from batch 2014-2017 of the Faculty of Economics and the Faculty of Science and Technology, Sanata Dharma University. The sampling technique employed was purposive sampling. The data analysis methods were the Chi-Square test and the Two Independent Sample Test with Mann Whitney Test. The test results show that 1) GPA factor significantly influences students' financial literacy,2) gender and allowance do not affect students' financial literacy,3) there are differences in financial literacy between students of the Faculty of Economics and the Faculty of Science and Technology, in which students of the Faculty of Economics have higher financial literacy level.
\end{abstract}

Keywords: Students’ Financial Literacy; Gender; GPA; Allowance.

\begin{abstract}
Abstrak
Penelitian ini bertujuan untuk mengetahui: 1) faktor-faktor yang mempengaruhi literasi keuangan mahasiswa di antaranya jenis kelamin, indeks prestasi kumulatif (IPK) dan uang saku; 2) perbedaan literasi keuangan antara mahasiswa Fakultas Ekonomi (FE) dan Fakultas Sains dan Teknologi (FST). Populasi dalam penelitian ini adalah mahasiswa aktif Angkatan 2014-2017 FE dan FST Universitas Sanata Dharma. Teknik Pengambilan sampel menggunakan Purposive Sampling. Metode analisis data adalah uji Chi-Square dan Two Independent Sampel Test Mann Whitney. Hasil pengujian menunjukkan bahwa 1) faktor IPK berpengaruh signifikan terhadap literasi keuangan mahasiswa, 2) faktor jenis kelamin dan uang saku tidak berpengaruh terhadap literasi keuangan mahasiswa, 3) terdapat perbedaan literasi keuangan antara mahasiswa FE dan FST, dimana mahasiswa FE memiliki literasi keuangan yang lebih tinggi.
\end{abstract}

Kata kunci: Literasi Keuangan Mahasiswa; Jenis Kelamin; IPK; Uang Saku.

How to Cite: Egesta, E., Rahayu, C. W. E., \& Rahmawati, C. H. T. (2021). Factors Affecting Student's Financial Literacy (A Study on the Students of the Faculty of Economics and the Faculty of Science and Technology of Sanata Dharma University Yogyakarta). Media Ekonomi dan Manajemen, 36(1), 27-38. doi: http://dx.doi.org/ 10.24856/mem.v36i1.1577. 


\section{INTRODUCTION}

In daily life we cannot escape from various economic activities. The important role of money in the economy makes many people work hard to earn money to meet their needs. However, whether we realise it or not, if it is not accompanied by good management, no matter how hard we try to earn money, the money we earn will always feel not enough. The ability and knowledge possessed by someone to manage their financial resources to achieve prosperity is called financial literacy.

Financial literacy is an important thing. By having a good comprehension on finance, we can avoid various financial problems. According to one of Indonesia's financial consulting services, Financial Wisdom Indonesia, there are at least four impacts from low financial knowledge, among others are low savings ratios, low investment ratios, consumerism culture and rampant bulging investments (wWw. financialwisdom.id, 2017).

In 2017, the Financial Services Authority (OJK) conducted a National Survey on Financial Literacy in 35 provinces in Indonesia, and found that the Indonesian people's financial literacy index was only $29.7 \%$. Despite having increased from 2013 which was $21.8 \%$, this means that only about 30 out of 100 residents have good understanding and are well literate in financial institutions and financial service products. This is one of the causes of why there are still many Indonesian people who become victims of illegal investment. The rise of bulging investment has a negative impact on the nation's economy (OJK, 2017).

During their study, college students will be given the trust to manage their finance independently without any supervision from their parents. At this time, the students' abilities and knowledge on financial management will be tested. Mistakes in making decisions can result in financial difficulties, especially since students do not have their own income and mostly still rely on the allowance from the parents. Limited knowledge and incorrect way of management can make the money given by parents becomes insufficient to meet the students' daily needs. Therefore, many students often have to find loans or even work to earn extra money.

The subjects of this study were the students of the Faculty of Economics and the Faculty of Science and Technology. Students are a group of people that is prone to experiencing financial difficulties because during their study, students are to live independently. With limited allowance, students must be able to manage the money given by their parents in order to meet all their needs of both meal and study. Therefore, it is necessary to have good and proper knowledge as well as management so that students can avoid financial difficulties.

The low level of students' financial literacy can be caused by the unequal basic financial education provided to students, so that students' understanding of financial management is also limited. Learning in universities especially in certain study programs can affect one's understanding of financial literacy and how to manage their finances. In addition to uneven education, there are many factors that influence students' financial literacy. Furthermore, studies conducted by Khrishna (2010), Nababan \& Sadalia (2013), as well as Margaretha \& Pambudhi (2015) state that the factors affecting financial literacy are gender, GPA, study programs, work experience, residence and parents' income.

There are several studies explaining factors that affect financial literacy but there are inconsistencies in those research results. For gender variable, research by Margaretha and Pambudi (2015), Maulani (2016), and Herawati (2017) show that gender affects financial literacy. Those studies reveal that women have higher financial literacy than men. However, that research result is different from the 
research conducted by Jian (2017), Mandala and Wiagustini (2017), and Irman (2018) which show that gender has no effect on financial literacy.

Meanwhile, for the GPA variable, research conducted by Margaretha and Pambudi (2015), Wijayanti et.al. (2016), Maulani (2016), Mandala and Wiagustini (2017), and Irman (2018) unveil that the GPA has an effect on financial literacy. The studies found that the higher the GPA, the better the financial literacy. However, on the contrary, research by Rita and Pesudo (2014) and Ismail (2018) show that the GPA has something to do with financial literacy.

Then for the allowance variable, research by Sulaeman (2012), Nidar and Bestari (2012), and Megasari (2014) show that allowance affects financial literacy. Those studies conclude that the higher someone's allowance, the better his/her financial literacy is because he/she can allocate the funding sources for savings or investment. However, that research result is different from research conducted by Rachmasari (2018) which shows that allowance does not affect someone's financial literacy.

In this study, the researchers used gender, GPA and allowance as the factors that influence students' financial literacy because these factors are the inherent variables in the students' identity.

\section{LITERATURE REVIEW}

Rachmasari (2018) state that financial literacy is the individual's ability to make judgments and effective decisions related to financial management. Meanwhile, according to the OJK in the Indonesian Financial Literacy National Strategy (2017), financial literacy is knowledge, skill and belief that influence the attitudes and behaviour to improve financial management decisions in achieving prosperity. Based on the definitions above, it can be concluded that financial literacy is the knowledge and ability possessed by individuals to manage all of their financial resources so that they can make effective financial decisions.

According to Morticone (2010), factors such as demographic characteristics, family background, wealth, and time preference can influence someone's financial literacy. On the other hand, Khrisna (2010), Nababan and Sadalia (2013), and Margaretha and Pambudhi (2015) affirm that gender, GPA, study program, working experience, residence, and parents' income are factors that influence financial literacy. In this study, some factors that affect financial literacy are gender, GPA, and allowance.

The first factor affecting someone's financial literacy is gender. According to Irman (2018), gender is the biological difference between female and male since someone was born. Female and male have special conditions that are different, both in physical and psychological terms. These differences are the source of different functions and roles carried by female and male. Stendardi \& Graham (2006) found that female and male tend to look at money and financial affairs very differently. Stendardi \& Graham (2006) state that female tend to see money as a pool while male see money as a flow. Because of this difference, Stendardi \& Graham (2006) state that female tend to be more risk averse because they have to protect their (limited) pool of money, while male tend to be less risk averse because the flow of money will provide new money to replace the lost money. Margaretha and Pambudi (2015) found that gender affects financial literacy. This research result is supported by Bank Indonesia's (BI) survey result which shows that women have higher financial literacy than men (Wijayanti et al., 2016). Women are better at managing finances than men because they are more keen on understanding matters related to finance. Hence, women are more dominant in managing finances than men. 
The second factor that affects financial literacy is the GPA. Grade Point (GP) and Grade Point Average (GPA) are two different things. If GP shows the grade per semester achieved by a student, then the GPA is the total number of grades obtained by students in each semester which is calculated based on the number of credits that have been taken. Grade Point Average (GPA) is influenced by the value of the Grade Point (GP) and the quality of grades for each course. The better the grade quality of each course, the higher the student's Grade Point Average (GPA) (Irman, 2018). The GPA is a benchmark for a student's academic intelligence. A high GPA indicates that the student has good academic ability and understanding of what he or she has learned. According to Margaretha and Pambudi (2015), a student with a higher GPA has fewer financial problems than a student with a lower GPA. Therefore, students who have higher GPAs will have better financial literacy than students with low GPAs.

The third factor that affects financial literacy is allowance. In the online Kamus Besar Bahasa Indonesia, allowance means the money that is brought for any purposes; pocket money. As a student, monthly allowance is the most important thing. For most students, allowance from their parents is the only income that can be used to meet all their daily needs and college needs. The large amount of allowance from parents will train their child to manage his/her finances wisely. Yates \& Ward (2011) found that generally people who have a high income will achieve better financial literacy levels in managing their finances. This happens because they can invest in education to increase their knowledge especially in financial knowledge.

\section{Hypothesis Development Gender to Financial Literacy}

According to Irman (2018), gender is a biological and physiological difference that can distinguish male and female. The difference is the source of the different functions and roles carried out by male and female. If we pay attention to the different roles and functions carried by male and female, we can see that the movements or trips made by male are different from the movements or trips made by female (Irman, 2018). Margaretha \& Pambudi (2015) found that gender influenced students' financial literacy. The results of the study by Margaretha and Pambudhi were also supported by the results of a Bank Indonesia (BI) survey that female have higher levels of financial literacy than male (Wijayanti et.al, 2016). Women generally take longer to make a buying decision than men. Women are more keen on learning things related to financial concepts and on making both short and long-terms financial planning. Women are more dominant in managing finances than men. Thus, women have higher level of financial literacy than men. From the explanation above, a hypothesis can be formulated:

H1 : Gender affects financial literacy.

\section{Grade Point Average (GPA) to Financial Literacy}

According to Salam (2004), GP is a figure that shows the students' achievement for one semester, which is calculated by a predetermined formula. While the GPA is a figure that shows the achievement of the students starting from the first semester to the last semester they have taken. A study conducted by Wijayanti et al (2016) found that there is a positive and significant influence of GPA on financial literacy. Grade Point Achievement can reflect the students' intellectual level. Students who have high intellectual level will tend to be more knowledgeable about financial concepts so that they have high financial 
literacy as well (Maulani, 2016). Students' academic achievement, in this context is the GPA, has a relationship with students' financial knowledge which is useful for managing their personal finances. Thus, the higher the student's GPA, the better his/her level of financial literacy. Conversely, the lower the GPA, the worse his/her level of financial literacy. From the explanation above, this hypothesis can be formulated:

\section{H2 : Grade Point Average affects financial literacy.}

\section{Allowance to Financial Literacy}

According to Collins dictionary.com (as stated in Hartanto, 2016), allowance is a small amount of money given to children by parents as a weekly allowance. For most students, allowance is the only income that can be used to meet their needs during their studies. Herlindawati (2015) found that income had a positive effect on the students' personal financial management. The large amount of allowance from parents will train a student to manage his/her finances wisely. Learning money management is one of the most important things that students must do because it affects their financial literacy skills. Thus, students' allowance has a significant effect on financial literacy. This is in line with Nidar and Bastari's (2012) research which shows that allowance affects one's financial literacy. From the explanation above, a hypothesis can be formulated:

H3 : Allowance affects financial literacy.

\section{Differences in Financial Literacy between The Students of The Faculty of Economics and The Faculty of Science and Technology}

The students' study programs will have an impact on their daily behavior including financial management, which will certainly have an impact on their financial literacy level. Students with a background in Economics Study Program have directly learned everything related to economics, including financial literacy. This is different from students with a background in the Science and Technology Study Program who do not receive any lesson on economics including financial literacy. This will certainly have an impact on differences in understanding and ways of financial management between students of the Faculty of Economics and students of the Faculty of Science and Technology.

A study conducted by Rosacker $e t$ al. (2010) reveals that a financial literacy training provides significant advantages for Economics students. Students majoring Economics Study Program tend to have higher levels of financial literacy than nonEconomics students. This is occurs because Economics students learn basic and specific financial knowledge, have a deeper ability to understand, read, and analyse financial reports in various media, and possess a bigger interest and concern in financial issues. Furthermore, according to Kusumawardhani, Cahyani and Ningrum (2020), the opportunity for learning about finance and having financial training for Economics students, referring to the curriculum, is higher than for nonEconomics students. Therefore, there are differences in terms of the financial literacy level between students of the Faculty of Economics and students of the Faculty of Science and Technology. This corresponds with research conducted by Rosacker et al. (2010), Margaretha and Pambudi (2015), Lantara and Kartini (2016) and Kusumawardhani et al. (2020) which shows that the financial literacy levels between Economics and nonEconomics students are different. Based on the results of the above explanation, the hypothesis can be formulated:

$\mathrm{H} 4$ : There is a difference in the financial literacy of the Students of the Faculty of Economics and the Students of the Faculty of Science and Technology of Sanata Dharma University 
Based on the reference to the theoretical foundation, Figure 1 depicts the frameworks and the research proposed hypothesis.

\section{RESEARCH METHODS}

The population in this study were active students of the Accounting, Management and Economics Study Program, Faculty of Economics and the Mechanical Engineering, Informatics Engineering, Electrical Engineering and Mathematics, Faculty of Science and Technology of Sanata Dharma University batch 2014-2017. The following data were the amount of population that the researchers obtained from the Secretariat of the Faculty of Economics and the Faculty of Science and Technology of Sanata Dharma University.

The sampling technique used was purposive sampling. In this study, the researchers considered several things related to the respondents who would become the sample of the study, namely: (1) Active students of the Faculty of Economics from the Accounting, Management and Economics Study Program and active students of the Faculty of Science and Technology from the Mechanical Engineering, Informatics Engineering, Electrical Engineering and Mathematics Study Program at Sanata Dharma University. (2) Students who may become the subjects of the study were students from batch 2014 to 2017.

\section{Descriptive Analysis}

Descriptive statistics provided an overview of the level of financial literacy that can be seen from the average (mean), standard deviation, maximum value and minimum value. The following was the formula for calculating financial literacy according to Margaretha \& Phambudi (2015):

$$
\text { Literacy level }=\frac{\text { Respondents }^{\prime} \text { correct answers }}{\text { total of questions }} \times 100 \%
$$

Chi Square $\left(\chi^{2}\right)$

According to Uyanto (2009), Chi Square test $\left(\chi^{2}\right)$ was used to test whether two categorical variables are independent or associated. In this study, the researchers used a statistical test with chi square because the data in the study were categorical. In addition, Chi Square test was used because one of the chi square test functions was to look at the interdependencies between variables. Chi Square was classified in non-parametric statistics so that it did not require the conditions of normal distribution. The hypothesis decision wasdetermined by comparingthe value of $\chi^{2}$ count with the $\chi^{2}$ table.If the $\chi^{2}$ count $\leq \chi^{2}$ table, then the Ho was accepted. If the $\chi^{2}$ count $>$ $\chi^{2}$ table, then the Ho was rejected. The value ofsig was also compared to the value of $\alpha$, if the probability (sig) $>0.05$, then the Ho was accepted. If theprobability(sig) $\leq$ 0.05 , then the Ho was rejected.

\section{Two Independent Samples Test with Mann Whitney Test}

According to Priyatno (2012), Two Independent Samples Tests or two free sample tests are used to determine whether there is a difference between two independent data groups. This analysis can measure ordinal type of data, intervals and ratios. In addition, because it is free or independent, the number of samples in each region (variable) does not have to be the same (Santoso, 2012).

The type of data in this study was interval and the sample in the study consisted of two samples that were not correlated (independent), namely students of the Faculty of Economics from the Accounting, Management and Economics Study Program and students of the Faculty of Science and Technology from the Mechanical Engineering, Informatics Engineering, Electrical Engineering, and Mathematics Study Program at Sanata Dharma University. Therefore, the statistical technique used was the 
comparison of two independent samples with the Mann Whitney method. Testing principles were conducted by comparing probability values of (sig) and $\alpha$.

\section{RESULT AND DISCUSSION}

\section{Respondents' Characteristics}

The results of the study regarding the respondents' characteristics can be described as follow: (1) Respondents' characteristics based on the faculty. There are $56.2 \%$ Faculty of Economics students with the distribution in each study program as follow: Management (25.9\%), Accounting $(24.8 \%)$, and Economics (5.5\%). There are $43.8 \%$ students of the Faculty of Science and Technology with the distribution in each study program as follow: Mechanical Engineering (14.5\%), Electrical Engineering (11.3\%), Informatics Engineering (10.6\%) and Mathematics (7.4\%). (2) Respondents' characteristics based on gender consist of $50.4 \%$ male and $49.6 \%$ female. (3) Respondents' characteristics based on GPA consist of students with <2.5 GPA (7.6\%), $2.5-3.00$ GPA $(32.5 \%)$ and > 3.0 GPA (59.9\%). Therefore, it can be concluded that the majority of respondents are students who have a GPA > 3.00. (4) Respondents' characteristics based on allowance consist of students with an allowance of $<\mathrm{Rp}$ 1,500,000 (52\%), between Rp 1,500,000 Rp 2,000,000 (35\%) and >Rp 2,000,000 $(13 \%)$. Therefore, it can be concluded that the majority of respondents are students with an allowance of $<$ Rp 1,500,000.

\section{Descriptive Analysis}

Based on the descriptive analysis results, it can be seen that the lowest value is $35 \%$ and the highest value is $100 \%$. This shows that from 20 statements on financial literacy, there were respondents who could only answer 7 statements correctly and accurately (35\%). However, there are also respondents who are able to answer all statements correctly and accurately $(100 \%)$. The overall average value (mean) of answers from respondents is $74 \%$. This means that the financial literacy of students in the Faculty of Economics and the Faculty of Science and Technology is in the moderate category (60\%-79\%) with a standard deviation value of financial literacy of $12 \%$ which means that respondents' answers vary.

Based on the category of financial literacy, it is found that there are 44 students who have low financial literacy $(11.61 \%)$ of the total respondents. In addition, there are 92 students with high financial literacy category $(24.27 \%)$. Most of the students who became the respondents in this study (243 people or around $64.12 \%$ ) are in the moderate category of financial literacy. The categories of financial literacy weredecided based on the number of correct answers obtained by the respondents. The more correct answers an individual obtained, the higher the financial literacy of the individual was.

\section{Effect of Gender on The Students' Financial Literacy}

The first hypothesis test results ( $\mathrm{H} 1)$ show that gender does not affect the students' financial literacy. Based on the Chi Squaretest results, the value of $\chi^{2}$ count is smaller than $\chi^{2}$ table $(1.652<$ 5.991) and p.value (sig) is bigger than $\alpha$ $(0.438>0.05)$. Therefore, in this case, gender does not affect the financial literacy of students. This is consistent with the study conducted by Mandala \& Wiagustini (2017) which states that gender does not affect financial literacy. This can happen because both male and female students get the same treatment and knowledge in receiving materials so that both male and female students are familiar with various financial terms, forms of financial management and financial products (Irman, 2018). Furthermore, equal rights in 
education and equal freedom of access to information make both male and female students have the same opportunity in obtaining various knowledge about financial management and financial products.

Similar results were stated by Jian (2017) in the study entitled "Differences in Financial Literacy of Faculty of Economics of Sanata Dharma University Students Based on Gender" that there is no difference in terms of financial literacy of Faculty of Economics of Sanata Dharma University students based on gender, meaning that different gender does not determine differences in financial literacy because male and female have balanced knowledge and abilities regarding finance. According to Jian (2017), both male and female have the same knowledge and abilities because there are similar conditions for male and female to obtain opportunities and their rights as humans to be able to play a role and participate in political, legal, economical, social, cultural, educational, national defense and security activities and enjoy the results of development. In this study, both male and female have the same ability and knowledge about finance, so it does not cause differences in financial literacy.

\section{Effect of GPA on The Students' Financial Literacy}

The second hypothesis test results (H2) show that GPA affectsthe students' financial literacy. Based on the Chi Squaretest results, the value of $\chi^{2}$ count is bigger than $\chi^{2}$ table $(28.337>9.487)$ and p.value (sig) is smaller than $\alpha(0.000<$ 0.05). Therefore, in this case, the GPA affects the financial literacy of students. This study shows that the higher the GPA of a student, the higher the student's financial literacy. The GPA reflects the intellectual abilities of students, the high student GPA can be used as an indicator that the student is diligent in learning and has a good ability to understand the materials so that many students with high GPA generally have broader knowledge compared to students with lower GPA. The ability to understand the materials well makes students with high GPA have better financial knowledge and concepts so that their financial literacy is also better compared to the students with lower GPA. This is consistent with the study conducted by Irman (2018) stating that the GPA affects the level of financial literacy which means that students with a GPA > 3.00 will have high financial literacy.

\section{Effect of Allowance on Students' Financial Literacy}

The third hypothesis test results (H3) show that allowance does not affect the students' financial literacy. Based on the Chi Squaretest results, the value of $\chi^{2}$ count is smaller than $\chi^{2}$ table $(4.898<$ 9.487) and p.value (sig) is bigger than $\alpha$ $(0.298>0.05)$. Therefore, in this case, allowance has no effect on the students' financial literacy. Thus, the amount of the monthly student allowance does not have an impact on the students' financial literacy. This is consistent with the results of the study conducted by Rachmasari (2018), stating that the amount of monthly allowance had no significant effect on financial literacy. This can happen because of poor student personal financial management. The amount of the allowance does not guarantee that students can manage their finances well.

According to Yates \& Ward (2011), people who have high income in general will have better levels of financial literacy in managing finances. Thus, students who have higher allowance should have the ability to manage finances better because they can freely allocate the sources of funds to save or invest. But in reality, the large amount of allowance does not make students allocate their funds to save and invest. Instead, the funds are spent to shop and entertain themselves. 
This is due to a lavish lifestyle and the students' lack of sense of responsibility. Based on the results of interviews, it is found that some students often experience a deficit of allowance even though their allowance is quite large. The allowance deficit occurs because of the habit of hanging out in cafes, eating in shopping centers (malls), watching at the cinema and shopping for various things that they desire such as clothes, bags, makeup and skincare. Due to these habits and lifestyles, the amount of student allowance has no effect on the students' financial literacy.

\section{The Difference between Students in The Faculty of Economics and the Faculty of Science and Technology in Terms of Financial Literacy}

The fourth hypothesis test results (H4) show that there is a difference in terms of financial literacybetween the students of the Faculty of Economics and the students of the Faculty of Science and Technology. The value of Asymp.Sig $<\alpha$ $(0.000<0.05)$. This means that there is a difference in terms of financial literacy between the students of the Faculty of Economics and the students of the Faculty of Science and Technology.

Based on Table 6, the mean rank valueof the Faculty of Economics is 208.73 while the mean rank valueof the Faculty of Science and Technology is 165.97. This means that the Faculty of Science and Technology has a lower mean rank compared to students of the Faculty of Economics. Thus, it can be said that the Faculty of Economics students have higher financial literacy level than the Faculty of Science and Technology students. This is consistent with the findings from Rita \& Pesudo (2014) that the Faculty has a significant effect on financial literacy. Faculty of Economics students have better financial literacy compared to Faculty of
Science and Technology students. This is because the disciplines pursued as Economics students make the Faculty of Economics students learn more about the economy and various financial concepts and knowledge.

In addition, students of the Faculty of Economics get Financial Management course in accordance with the curriculum guidelines of each study program. On the other hand, the Faculty of Science and Technology students study exact science more. Students of the Faculty of Science and Technology do not get the basic education about finance and manage finance on their learning materials in class so the students of the Faculty of Science and Technology have to try harder to find information and learn various knowledge about the fundamentals of self-taught education. The knowledge possessed by students of the Faculty of Science and Technology only comes from the experience of simple transaction activities carried out in daily life such as the use of bank products in the form of savings. The high level of financial literacy occurs because Economics students learn basic and specific financial knowledge, have a deeper ability to understand, read, and analyse financial reports in various media, and possess a bigger interest and concern in financial issues compared to students of the Faculty of Science and Technology. Therefore, there are differences in terms of financial literacy between the students of the Faculty of Economics and the students of the Faculty of Science and Technology of Sanata Dharma University. The result of the study corresponds with research conducted by Rosacker et al. (2010), Margaretha and Pambudi (2015), Lantara and Kartini (2016) and Kusumawardhani et al. (2020) which show differences in terms of financial literacy between Economics and non-Economics students. 


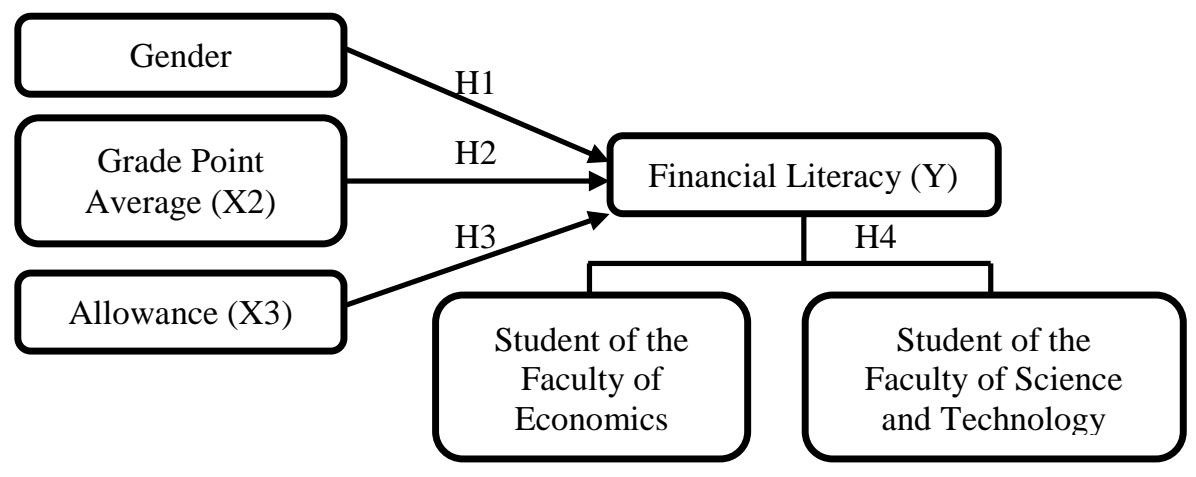

Figure 1. Conceptual Framework

Table 1. Total Population Period 2018/2019

\begin{tabular}{lrrrrr}
\hline \multicolumn{5}{c}{ Faculty of Economics } & \multirow{2}{*}{ Total } \\
\cline { 2 - 5 } \multicolumn{1}{c}{ Study Program } & $\mathbf{2 0 1 4}$ & $\mathbf{2 0 1 5}$ & $\mathbf{2 0 1 6}$ & $\mathbf{2 0 1 7}$ & \\
\hline Management & 120 & 198 & 215 & 209 & 742 \\
Accounting & 41 & 146 & 161 & 183 & 531 \\
Economics & 0 & 0 & 41 & 60 & 101
\end{tabular}

Number of Active Student of the Faculty of Economics Faculty of Science and Technology

$\begin{array}{lrrrrr}\text { Mechanical Engineering } & 43 & 126 & 138 & 135 & 442 \\ \text { Electrical Engineering } & 28 & 48 & 64 & 84 & 224 \\ \text { Informatics Engineering } & 60 & 102 & 120 & 126 & 410 \\ \text { Mathematics } & 13 & 22 & 33 & 48 & 116\end{array}$

Number of Active Student of the Faculty of Science and Technology 1192

TOTAL NUMBER OF POPULATION 2566

Source: Primary Data Processed, 2018

Table 2. Chi-Square Test Results on Gender*Financial literacy

\begin{tabular}{cccc}
\hline & Value & Df & Asymp. Sig. (2-sided) \\
\hline Pearson Chi-Square & 1.652 & 2 & 0.438 \\
\hline
\end{tabular}

Source: Primary Data Processed, 2018

Table 3. Chi-Square Test Results on GPA*Financial literacy

\begin{tabular}{cccc}
\hline & Value & Df & Asymp. Sig. (2-sided) \\
\hline Pearson Chi-Square & 28.337 & 4 & 0.000 \\
\hline
\end{tabular}

Source: Primary Data Processed, 2018

Table 4. Chi-Square Test Results on Allowance*Financial literacy

\begin{tabular}{cccc}
\hline & Value & df & Asymp. Sig. (2-sided) \\
\hline Pearson Chi-Square & 4.898 & 4 & 0.298 \\
\hline Source: Primary Data Processed, 2018
\end{tabular}

Table 5. Mann Whitney Test Results

\begin{tabular}{cc}
\hline & Financial Literacy \\
\hline Mann-Whitney U & 13689.500 \\
Z & -3.800 \\
Asymp. Sig (2-tailed) & .000 \\
\hline Source: Primary Data Processed, 2018
\end{tabular}


Table 6. Mann Whitney Descriptive Statistics Results

\begin{tabular}{ccccc}
\hline & Faculty & N & Mean Rank & Sum of Ranks \\
\hline Financial & Economics & 213 & 208.73 & 44459.50 \\
Literacy & Science and Technology & 166 & 165.97 & 27550.50 \\
\cline { 2 - 5 } & Total & $\mathbf{3 7 9}$ & &
\end{tabular}

Source: Primary Data Processed, 2018

\section{CONCLUSION AND RECOMMENDA- TION}

This study aims to determine the factors that influence the financial literacy of the students of the Faculty of Economics and the Faculty of Science and Technology of Sanata Dharma University. Based on the results of data testing that has been conducted in this study, the following conclusions can be drawn: (1) Students' gender does not affect the students' financial literacy in the Faculty of Economics and the Faculty of Science and Technology, Sanata Dharma University; (2) Students' GPA affects the students' financial literacy in the Faculty of Economics and the Faculty of Science and Technology of Sanata Dharma University; (3) The amount of student allowance has no effect on the students' financial literacy in the Faculty of Economics and the Faculty of Science and Technology of Sanata Dharma University; (4) There is a difference in financial literacy between students of the Faculty of Economics and students of the Faculty of Science and Technology of Sanata Dharma University. Students of the Faculty of Economics have higher financial literacy compared to students of the Faculty of Science and Technology.

This study has several limitations, among other are that researchers only use the factors of gender, GPA and allowance to students' financial literacy. Therefore, future research is expected to use broader factors such as origin, age, level of education, parents' knowledge and education. In addition, based on the results of the study, it is found that the level of financial literacy of the students of the Faculty of Economics and the Faculty of Science and Technology of Sanata Dharma
University is in the moderate category with an average value of $74 \%$. Thus, it is expected that in the future, students will be more initiative in finding information about financial service products so that they can avoid financial difficulties and informal financial service institutions (bulging investments). It is also expected that in the future, differences in study programs do not become a restriction for everyone to have adequate knowledge about finance and financial services institutions to improve their prosperity.

\section{REFERENCES}

Hartanto, P. H. R. (2016). Pengaruh Gaya Hidup, Kelompok Acuan, dan Uang Saku Terhadap Pola Konsumsi Mahasiswi Dalam Menggunakan Jasa Salon Di Kota Yogyakarta (Studi Kasus pada Mahasiswa Universitas Sanata Dharma Yogyakarta). Skripsi. Yogyakarta: Universitas Sanata Dharma.

Irman, M. (2018). Analisis Faktor-Faktor Yang Mempengaruhi Financial Literacy Di Kalangan Mahasiswa Universitas Muhammadiyah Riau (UMRI) Pekanbaru. Journal of Economic, Busines and Accounting (Costing), 1(2), 180-197.

Ismail, M. (2018). Pengaruh Status Ekonomi Orang Tua, IPK, dan Pembelajaran di Perguruan Tinggi terhadap Literasi Keuangan Mahasiswa. Doctoral dissertation. Surabaya: Sekolah Tinggi Ilmu Ekonomi Perbanas. 
Jian, A. K. (2017.) Perbedaan Financial Literacy Mahasiswa Fakultas Ekonomi Universitas Sanata Dharma Berdasarkan Gender. Skripsi. Yogyakarta: Universitas Sanata Dharma.

Kusumawardhani, R., Cahyani, P.D., \& Ningrum, N.K. (2020). Analisis Perbedaan Tingkat Literasi Keuangan Antara Mahasiswa Fakultas Ekonomi Dan Mahasiswa Fakultas Non-Ekonomi. Mix-Jurnal Ilmiah Manajemen, 10(1), 15-28.

Lantara, I.W.N., \& Kartini, N.K.R. (2015). Akselarasi Program Edukasi Keuangan Melalui Kolaborasi Bank Indonesia, Lembaga Keuangan, dan Perguruan Tinggi. Jurnal Riset Manajemen Sekolah Tinggi Ilmu Ekonomi Widya Wiwaha Program Studi Magister Manajemen, 2(2), 95113.

Mandala, I. G. N. N. \& Wiagustini, L. P. (2017). Pengaruh Variabel Sosial Ekonomi, Demografi, dan IPK Terhadap Financial Literacy. EJurnal Ekonomi dan Bisnis Universitas Udayana, 6(12), 42254254

Margaretha, F. \& Pambudhi, R. A. (2015). Tingkat Literasi Keuangan pada Mahasiswa S-1 Fakultas Ekonomi. Jurnal Manajemen dan Kewirausahaan, 17(1), 76-85.

Maulani, S. (2016). Analisis Faktor-Faktor yang Mempengaruhi Literasi Keuangan (Studi Pada Mahasiswa Juruan Manajemen Fakultas Ekonomi Universitas Negeri Semarang Aktif Semester Genap Tahun 2015/2016). Doctoral dissertation. Semarang: Universitas Sebelas Maret.

Nababan, D. \& Sadalia, I. (2013). Analisis Personal Financial Literacy dan Financial Behavior Mahasiswa Strata I Fakultas Ekonomi Universitas Sumatera Utara. Media Informasi Manajemen, 1(1), 1-15.
OJK. (2017). Strategi Nasional Literasi Keuangan Indonesia (SNLKI). Jakarta: OJK.

Priyatno, D. (2012). Belajar Praktis Analisis Parametrik dan Non Parametrik dengan SPSS. Yogyakarta: Gava Media.

Rachmasari, A. (2018). Faktor-Faktor Yang Mempengaruhi Literasi Keuangan Mahasiswa. Skripsi. Yogyakarta: Universitas Islam Indonesia.

Rita, M. R. \& Pesudo, B. C. A. (2014). Apakah Mahasiswa Sudah Melek Keuangan?. Jurnal Dinamika Akuntansi, Keuangan, dan Perbankan. 3(1), 58-65.

Rosacker, K. M. S., Ragothaman \& Gillispie, M. (2010). Financial Literacy of Freshmen Business Scholl Students. College Student Journal, 43(2), 391-399.

Santoso, S. (2012). Aplikasi SPSS pada Statistik Nonparametrik. Jakarta: PT. Elex Media Komputindo.

Uyanto, S. S. (2009). Pedoman Analsis Data dengan SPSS. Yogyakarta: Graha Ilmu.

Wijayanti, A., Grisvia \& Rahmawati, F. (2016). Pengaruh Jenis Kelamin, IPK dan Semester Terhadap Literasi Keuangan Mahasiswa Prodi S1 Ekonomi Pembangunan Universitas Negeri Malang. Jurnal Pendidikan Ekonomi, 9(1), 87- 96.

Yates, D. \& Ward, C. (2011). Financial Literacy: Examining The Knowledge Transfer Of Personal Finance From High School To College To Adulthood. American Journal of Business Education, 4(1), 65-78.

Yushita, A. N. (2017). Pentingnya Literasi Keuangan Bagi Pengelolaan Keuangan Pribadi. Jurnal Nominal, 6(1), 11-26. 